\title{
A comparative analysis of graduate employment prospects in European labour markets: a study of graduate recruitment in four countries
}

Branine, M. and Avramenko, A.

This is the peer reviewed version of the following article:

Branine, M. and Avramenko, A. 2015. A comparative analysis of graduate employment prospects in European labour markets: a study of graduate recruitment in four countries. Higher Education Quarterly. 69(4): pp.342-365. doi: 10.1111/hequ.12076

which has been published in final form at http://dx.doi.org/10.1111/ hequ.12076. This article may be used for non-commercial purposes in accordance with Wiley Terms and Conditions for Self-Archiving. 


\title{
A comparative analysis of graduate employment prospects in European labour markets: a study of graduate recruitment in four countries
}

\author{
AUTHOR, AUSPICIES \\ Mohamed Branine, Dundee Business School, Abertay University, \\ Alex Avramenko, Dundee Business School, Abertay University
}

\begin{abstract}
The aim of this paper is to provide a comparative analysis of higher education and the graduate labour markets in selected European countries (France, Germany, Spain and UK) in the context of the expectations of graduates and prospective employers, and respective recruitment and selection practices. Expectations of graduating students from a number of European collaborating universities are sought and analysed in order to find out about a match between the knowledge and skills of graduates and the needs of European employers. The study examines the process of graduate recruitment, employee and employer expectations, and the role of higher education institutions in meeting such expectations. Primary data was gathered from 252 employers and 485 final year (graduating) students through the use of questionnaires. The analysis of the data collected has revealed different approaches to but similar methods of graduate recruitment between the four countries. Despite the current differences in higher education systems and labour market trends, the expectations of employers and graduating students are more similar than different. It is concluded that EU graduates will have good employment prospects in an integrated labour market.
\end{abstract}

Keywords: graduate recruitment, employer expectations, European labour market; higher education

\section{Introduction}

Recent studies of graduate recruitment and employability in some European Union (EU) countries have concluded that there is a mismatch between the demand for and supply of graduates in European labour markets (Eurostat, 2014; Mourshed et al, 2014; Hurrell et al., 2011; Weitzel et al. 2008; Wilton, 2011; Helyer and Lee, 2012). Graduates are finding it increasingly difficult to gain appropriate employment at a time when they have freedom of movement and the choice of working in over twenty countries (Eurostat, 2014). The supply of graduates exceeds the demand for graduates in most of the EU labour markets. In the United Kingdom (UK), for example, a study of labour market trends between 1986 and 2006 identified a surplus of about one million graduates who cannot find jobs relevant to their degrees (Festead et al., 2007; Gomes, 2012). Although competition for graduate jobs has been the toughest ever graduate recruitment is still in the increase as companies attempt to recruit the best talent (PwC, 2011; Stephan and Silvia, 2008; Economist, 2011). 
Graduate underemployment has become a real problem, as many graduates are unable to utilise their knowledge and skills (Brown and Hesketh, 2004; Hurrell et al., 2011; Mourshed et al, 2014). The challenges that graduates face in a large and highly competitive EU labour market arise in part from the fact that there are different higher education systems across the EU that award a variety of qualifications that are supposed to give their holders better employability prospects. On the supply side, European labour markets reflect a wide variety of educational systems, qualifications and academic disciplines but the graduate jobs that are available (the demand side) are relatively homogeneous, limited in scope and increasingly competitive. Some studies have attempted to explore this phenomenon (Anderson and Witvliet 2008; Sackett and Lievens 2008; Broadbridge et al., 2009; Hurrell et al., 2011) in different sectors of the economy but have mainly concentrated on the relationship between the applicant (person) and the recruiter (organisation) and have overlooked the role of higher education institutions that prepare the person for work in the organisation. Higher education has become widely accessible as EU member states aspire to produce highly talented graduates to meet the demands of a knowledge economy and to reduce social and economic inequalities. However, as Wilton (2011, p. 85) asserted: 'the relationship between employability and employment is far from straightforward' despite the improvement in employability skills through higher education there are still many problems of graduate employment.

The person-organisation fit analysis that has dominated the literature on graduate recruitment (Garavan, 2007; Lievens et al., 2001) has restricted the scope for analysing and, hence, understanding the process of graduate recruitment because it excludes the role that higher education can play in the transition from study to workplace. Moreover, as far as European labour markets are concerned, there is limited information about the methods organisations throughout Europe use to select graduates from different countries, or about the extent to which such methods have been successful in attracting graduates who possess appropriate attributes that meet the current and future needs of employers. This study looks at the university, graduate, employer relationship in the context of employability that is 'the propensity of the individual student to get employment' (Harvey, 2001, p. 97), with the emphasis getting better understanding of globalising trends affecting graduate recruitment. Graduate employment is however a two-way process characterised by a match between graduate attributes and organisational features and it is influenced by a third factor contribution of the higher education institution. On the one hand, further and 
higher education is expected to prepare students with the necessary attributes for the world of work and to provide employers with a choice of talents for their current and future operations (Brennan and Little, 2010; Wilton, 2011 and Mazuki et al., 2011). It is generally assumed that after years of higher education graduates become confident thinkers, determined creators, flexible collaborators, ambitious enquirers or have a similar set of attributes. While being equipped with these attributes that are essential for employment in any organisation, they develop their own view of their future employers. On the other hand, organisational and job features are various and wide-ranging from the attractive reward package they provide to graduates to their reputation and market position. Graduates 'have a drive for career success and linear promotion, wanting to meet their own personal goals, develop themselves and take personal responsibility for their own career' (Broadbridge et al., 2009: 406). Employee-employer expectations as well as the process of graduate recruitment are the focus of this study but before discussing the study and its findings, a brief overview of current European labour market trends and higher education systems is provided below.

\section{Context and content of European labour markets}

European labour markets differ in size and composition but as EU integration progresses they have become more alike in their employment regulations, policies and practices and in the composition of the workforce. The adoption of the Social Charter (Teague and Grahl, 1991) and the implementation of an increasing number of directives have led to similar labour market trends despite the fact that some countries such as the UK are less regulated than others such as France and Spain. Common labour market trends include the increase in the service sector and the decline in the manufacturing and industrial sectors, the growth of small and medium-size enterprises and increasing levels of investment by non-European multinational companies. These changes have affected graduate recruitment as more and more graduates have had to seek employment in the service sector, small and medium-size enterprises and in non-European non-European multinationals (CIPD 2007; Anderson and Witvliet 2008; Chillas, 2010). The shift from manufacturing to a serviceoriented economy has to some extent led to a mismatch between the skills demanded and available skills, as graduates are not obtaining the qualifications that employers need (McKinsey and Company, 2014). In the UK, for example, the number of graduates completing mass-communication-related degrees continues to rise (Higher Education 
Statistics Agency, 2014), despite the fact that demand for media professionals has decreased sharply (High Fliers, 2014).

In the light of the increasing intensity and complexity of the business environment resulting from technological advances and globalisation, demand for relevant qualifications and skills is rising. According to the Office for National Statistics (ONS) (2013), non-graduates aged 21 to 30 have consistently higher unemployment rates than graduates (14\% for young non-graduates, compared with $9 \%$ of graduates), suggesting that getting a university degree improves job prospects. Interestingly however, the ONS (2013) also found that $47 \%$ of graduates are currently employed in jobs that do not require a higher qualification. The study by the ONS highlighted the rising demand of employers and also the competitive nature of labour market in the UK. Furthermore, while companies across Europe maintain they have difficulties in finding suitable candidates to fill their vacancies, over five million young people across the Europe are unable to find the job matching their levels of qualifications and aspirations (Mourshed et al, 2014). Although, these jobseekers are not a homogeneous grouping this fact indicates either a mismatch between employer and graduate expectations or the argument about an impact of globalising forces to the EU economy, as facilitating better conditions for employers and jobseekers to match up, is overemphasised (Camagni et al, 2012).

Other characteristics of the EU labour markets are the use of flexible working practices, the increasing participation of women, the increasing employment of migrant and mobile workers (Eurofound, 2007), high levels of unemployment, shortages in skilled labour and an ageing workforce. The use of flexible working practices is common across the EU (Brewster, 1998) and has traditionally been used for low-level jobs, mainly benefiting women balancing work and family commitments (Straub, 2007). Today all employees are expected to accept flexible working arrangements. Many graduates have had to start their first jobs on short-term or project-based contracts or on a part-time basis (Mckeown and Lindorf, 2010; Terjesen, Vinnicombe and Freeman 2007). In addition, university students are increasingly entering the labour market as part-time employees before graduation, working on average about 19.8 hours per week (Swain, 1999); more recently, the ONS (2014) reported that over a quarter of (27\%) students now work while in college or university. In a survey of over 4000 graduates across 75 countries, respondents were asked which benefits they would most value from an employer. The research found the 
graduates value training and development and flexible working opportunities over financial benefits (PwC, 2011).

These trends have had a significant impact on how employers attract and select future employees. Methods of graduate recruitment used in the 1990s were different from those used today. For example, a 1990s study of graduate recruitment in the UK found that application forms, the milk round (pre-screening interviews with graduates) and paper advertising were the most popular methods of recruitment (Keenan, 1995). Carroll et al. (1999) however noted that word-of-mouth recruitment is one of the most common recruitment methods adopted by SMEs in UK. By 2007, the use of the Internet, graduate agencies and graduate fairs had become the most popular methods (CIPD, 2007; Branine, 2008). Elsewhere in the EU the recruitment of graduates was often based on direct contact with graduates, through internships, word of mouth (Van Hoye and Lievens, 2007) and unsolicited applications (Dany and Torchy, 1994). Although these methods still exist, there have been many changes because of the recent advances in the use of information and communication technologies (Anderson and Witvliet 2008; High Fliers, 2014; PwC, 2011; Weitzel et al. 2008). In Germany, for example, the most popular method of recruitment in the top 1,000 companies is electronic. More than $89 \%$ of German companies use their company websites to advertise job vacancies and only $27 \%$ use print media (Weitzel et al. 2008). In France and Germany, establishing links with universities through internships, guest lectures, or sponsorships is another way of having direct contact with graduate applicants. High Fliers (2014) reports that in 2013 over $90 \%$ of employers in the UK have taken part in university careers fairs and organised their own on-campus recruitment presentations. The use of graduate recruitment agencies is on the increase throughout the EU but is still the least preferred method of recruitment in Germany and the Scandinavian countries (Jung, 2006). With a sample of 462 respondent organisations, the CIPD (2013) reports that the most effective methods for attracting candidates in the UK were through corporate websites, commercial job boards, apprenticeships and professional networking sites such as LinkedIn. In the UK, university-based career services play a significant role in supporting students, acting as the interface between students and potential employers (High Fliers, 2014). 
Selection methods such as interviews, tests and references are still used throughout the EU but have changed in their nature and level of use from one organisation to another and from one country to country. A study by Anderson and Witvliet (2008) of reactions to personnel selection methods in France, Holland, Portugal, Singapore, Spain and the United States of America found that the most popular methods among the respondents were interviews, work sample tests and curricula vitae (CV); and that the least popular methods were graphology, personal contacts and personality tests. The CIPD (2013) reports that interviews remain the most common selection method in the UK, whereby all the organisations that use interviews use face-to-face techniques, over half of them $(56 \%)$ telephone interviews and nearly a third of them (30\%) use video interviews. Other studies found that the use of psychometric testing was most popular in Finland, Portugal and Spain and least popular in Germany and the UK (Dany and Torchy, 1994; CIPD, 2013). Psychometric tests have become increasingly popular when organisations have to select from a large number of applicants. Assessment centres are most popular in the Netherlands, Finland, Spain and the UK. The use of references was less common in Spain and the Netherlands and most popular in Sweden, Norway, Ireland and the UK (Dany and Torchy, 1994; Burgess, 1997; CIPD, 2013). It is also common in France, Belgium, Germany and Spain to select applicants by competitive examination, or by requiring them to pass an induction or training course.

\section{Higher education: systems, changes and challenges}

It is often argued that the main role of higher education institutions is to prepare students for employment (Nabi and Bagley, 1998; Mazuki et al., 2011). In Greece and Portugal, graduate unemployment is as high as non-graduate unemployment (Mourshed et al, 2014). In the UK, the proportion of recent graduates who work in jobs not requiring knowledge and skills developed through higher education (Elias and Purcell, 2004) rose from 37\% in 2001 to 47\% in 2013 (ONS, 2013). As a result, according to McKinsey survey conducted August-September 2012 27\% young people in Europe have doubts about the value of post-secondary education and have opted out of pursuing higher education (Mourshed et al, 2014). However, it is also argued that the main aim of higher education is to 'develop the knowledge, skills, moral values, and understanding required in all aspects of life rather than knowledge and skills relating to only a limited field of activity' (Reid and Barrington, 1997, p. 47). It is suggested that university graduates already possess abilities and skills 
acquired from experience and from previous education. Higher education then builds on these by providing opportunities for further development of these skills and knowledge, which are then normally further enhanced through employment (Gush, 1996a; Etzkowitz and Leydesdorff, 1997; Boden and Nedeva, 2010). The responsibility for the development of graduate skills cannot therefore solely rest with higher education although its role cannot be underestimated. Widening participation in higher education by giving wider access to universities was expected to reduce differences between classes in society and to provide employment opportunities for all (Iannelli, 2007). EU member states' policies have been geared towards the mass production of graduates in order to achieve high levels of graduate employment, improved economic productivity and reduced social inequality. In the UK, for example, the paper Higher Ambitions, The Future of Universities in a Knowledge Economy by the Department for Business Innovation and Skills (2009) clearly stressed the need for wider access to highly selective universities for those from underprivileged backgrounds. Such policies have been aimed at increasing the number of graduates to meet the needs of increasingly competitive knowledge economies. However, skill shortages are still evident in some sectors of the economy, especially for jobs that require high levels of numeracy (Hilton, 2008; Mourshed et al, 2014; PwC, 2011). The move from élite to mass higher education over the last twenty years has created a supply of highly qualified (degree-holding) but not necessary talented and skilled labour. It is also argued that despite wider access to higher education, social and economic inequalities still exist (Hilton, 2008; Iannelli, 2007; Little, 2008; Mourshed et al, 2014; Purcell et al., 2005, 2006).

Different higher education systems and qualification frameworks still exist throughout the EU despite recent harmonisation efforts under the Bologna agreement. The British higher education system was different from that of most of other European countries at the beginning of Bologna Process in 1999 with the three cycle degree system: bachelor degrees followed by masters degrees and then doctorates (Watcher, 2004 In comparison, the Spanish higher education system was divided into three cycles: Diplomado courses last for three years, Licenciado courses last for five to six years and the final cycle is called Doctor. Normally the Licenciado is equivalent to the British Honours degree and is offered by university faculties (Facultades Universitiarias). In Germany, higher education is delivered in academic universities and applied universities (Fachhochschulen). Universities provide traditional academic education while the Fachhochschulen provide 
courses in applied sciences. Entry into higher education has become more competitive as strict selection criteria have been introduced for different disciplines. These examples illustrate the divergence of educational systems in EU member states although changes are in progress as the Bologna initiative is being implemented. The other distinction in higher education institutions, not affected by the Bologna process, is that they differ in perceived reputation in relation to their age and location rather than ranking typically driven by research (Maringe and Foskett, 2012). Old universities are perceived to be better than the new ones; ones in bigger cities are well known compared to the ones in small ones and large universities often receive more public acclamation than the small ones. Therefore, graduate employment prospects are very often affected by where rather than what the graduate studied (Iannelli, 2007). In France, for example, education at a Grande École gives far better access to an élite professional career than studying in a university does (Little, 2008; Brennan and Little, 2010).

EU Ministers of Education agreed at a meeting in Bologna in 1999 to work together to achieve greater compatibility between European higher education systems by establishing, by 2010, a common European higher education system that would be more transparent and internationally competitive (Rauner, 2008). The Bologna declaration included such initiatives as the encouragement of student and staff mobility between EU member states through joint and exchange education programmes. It also envisaged greater mobility of students within the EU for study and to broaden their experience (Department of Education and Skills, 2007). All EU member states have signed up to the Bologna objectives and more than 45 countries worldwide have recognised the proposed education structure and its qualifications. The Bologna model of a two-stage education structure is not too different from the current bachelor and master degree structure in the UK while in many other EU countries the adoption of the model has posed significant challenges because it requires considerable changes in their qualification systems. So far most of the countries signatory to the Bologna declaration have been unable to fit their qualification structures with those of the Bologna framework and have kept their own equivalent qualifications. As from 2005, following the Bergen Conference of European Ministers Responsible for Higher Education held on 19-20 May 2005 which emphasized the importance of harmonizing the degree learning outcomes, it has been recognised that a full convergence in terms of time spent on a degree is not as significant as the competencies and knowledge gained from such a degree. This was confirmed at another ministerial 
meeting held on 17-18 May 2007 in London, which reaffirmed that a good progress had been made towards the realisation of the European Higher Education Area (EHEA) in terms of mobility, recognition, lifelong learning and degree structures but there were still many obstacles towards the full achievement of the Declaration's objectives, especially the harmonisation of qualifications and employability. Moreover, the Budapest-Vienna Declaration of 12 March 2010 launched the EHEA and renewed the members' commitment to the full implementation of the agreed objectives but at the same time it was acknowledged that much still had to be done at the national and institutional levels to reach the projected goals. Fifteen years on, the Bologna declaration objectives are yet to be fully met but significant progress has been made in terms of academics and students' mobility, mutual confidence in and recognition of the member states' qualifications, and the promotion of quality standards of higher education within the EHEA and beyond as more and more countries have joined in. However, there are still many challenges to overcome like effective learning outcomes and employability, equitable access to higher education (social dimension) and life long learning (see Dima, 2014). The four EU countries involved in this study have been at the forefront in showing commitment and making significant progress towards the achievement of the Bologna Declaration objectives but it is yet clear to what extent their commitment has had any impact on graduate recruitment and graduate employability of their universities' graduates; and hence this is one of the objectives of this research study.

This study aims to review the university, graduate, employer relationship in four EU countries: France, Germany, Spain and the UK with respect to aforementioned influences on graduate recruitment in the context of globalisation and convergence thesis.

\section{The Study}

The research for this study was based on a combination of secondary and primary data. Secondary data was collected through a review of relevant literature, mainly in English, on labour market trends, higher education systems and graduate recruitment in the countries studied. Primary data was collected from four EU countries (France, Germany, Spain and the UK) through the use of questionnaires. Two types of questionnaire were used; one to gather data from prospective employers and the other to collect data from final-year 
students. The questionnaires were produced in English and then translated into the relevant European languages.

The employer questionnaire was divided into five sections aimed at collecting information about the organisation and its activities, the methods of recruitment and selection used, the graduate attributes and skills required, the provisions for graduate employment and career progression and the problems encountered in recruiting appropriate talents for their operations. A total of 500 questionnaires were sent by e-mail or by post to employers in the UK, selected randomly from the Prospects Directory, the Graduate Employment and Training Directory and the Times Top 100 Graduate Recruiters. About two thirds of employers contacted were large multinational companies and one-third small and medium enterprises. The response rate from the British sample was just above 30 percent (156). Also 220 questionnaires were sent by e-mail or distributed by post or by hand (depending on what was possible) as follows: 100 questionnaires to employers in France, 70 questionnaires to employers in Germany and 50 questionnaires to employers in Spain. The samples represented a mixture of different organisational sizes and sectors of the economy. The response rates varied from $46 \%$ in France to $58 \%$ in Germany and $20 \%$ in Spain. The overall response rate from employers was about $35 \%$ as only 252 of the returned questionnaires were usable.

Final-year student questionnaires were designed to collect data on graduate expectations of their future employers and on their experiences of applying for graduate employment. The questionnaires were distributed via career services in eight universities in the UK where European students on exchange programmes were pursuing their university education and also distributed directly through colleagues to final-year students in three universities in France, two universities in Germany and one university in Spain. A total of 800 questionnaires were distributed but the majority were distributed to home and EU students at UK universities. The response rate was about $60 \%$ as 485 usable questionnaires were returned (Table 1). The numbers of questionnaires returned by country were France (105), Germany (100), Spain (30) and the UK (250).

Table 1: Questionnaires distributed by country and response rate (\%)

Country France Germany Spain UK Total




$\begin{array}{llllll}\text { Employers } & 100(46 \%) & 70(58 \%) & 50(20 \%) & 500(30 \%) & 720(35 \%) \\ \text { Students } & 155(68 \%) & 180(55 \%) & 60(50 \%) & 405(62 \%) & 800(60 \%)\end{array}$

\section{The Findings}

Analysis of the data collected has revealed-several similarities as well as some differences in the process of graduate recruitment and selection between the four countries studied. There are signs of an emerging convergence in the practice of graduate recruitment among the four EU countries despite the prevalent differences in higher education systems and labour market trends. The findings are presented below under recruitment methods, selection methods, employer expectations and graduate expectations and experiences.

\section{Recruitment methods}

As it would have been expected, the most popular method of graduate recruitment was the Internet (Table 2). This is hardly surprising but the use of the Internet differed in nature, type and level of use from one country to another. In the UK, the most popular method was the company website followed by dedicated graduate recruitment websites. Some organisations used recruitment agencies and career centre websites. In France and Germany, most organisations used their websites and targeted recruitment media (newspapers and magazines) websites and, in most cases, used English as well as the home language. In Spain, they used company and national newspaper websites mainly in Spanish. The second most popular method was the use of graduate recruitment literature such as brochures, newsletters and national graduate recruitment directories, such as Prospects Directory, the Graduate Employment and Training Directory and Prospects Today in the UK, Berufsstart and Der Hobsons in Germany and El Pais and ABC in Spain. The use of national and international print media (newspapers and magazines) came third as all the respondents from large organisations (1000+ employees) in all the four countries said they used them. It seems that the use of the Internet has complemented rather than replaced organisational own printed literature and national or international print media for the advertising of job vacancies. The use of university career centres was common in France, Spain and the UK as more than 50\% of respondents from these countries said they used them although only about a third of German respondents used them. The use of presentations to final year students by management was significantly low in all four countries although slightly higher in the UK and France. 
Table 2: Methods of graduate recruitment by country

\begin{tabular}{|l|rrrrc|}
\hline \multicolumn{1}{|c|}{ Country } & France & Germany & Spain & UK & Overall \\
\hline Method & $\%$ & $\%$ & $\%$ & $\%$ & $\%$ \\
\hline Newspapers/magazines & 96 & 87 & 100 & 88 & 93 \\
Career fairs & 37 & 22 & 45 & 65 & 42 \\
Career centres & 52 & 33 & 58 & 60 & 51 \\
Milk round & 10 & 03 & 12 & 26 & 13 \\
Presentations & 20 & 15 & 10 & 22 & 17 \\
Careers literature & 100 & 98 & 100 & 95 & 98 \\
Recruitment agencies & 46 & 35 & 42 & 20 & 36 \\
Internet & 100 & 100 & 100 & 100 & 100 \\
Other & 52 & 40 & 37 & 45 & 44 \\
\hline
\end{tabular}

Moreover, there were some differences among the respondents in relation to the use of graduate recruitment methods such as career fairs, the milk round and recruitment agencies. In the UK, the so-called 'milk round' was used by $26 \%$ of respondents but appeared however to be less popular than methods such as graduate recruitment fairs $(65 \%)$. In other countries, the milk round was confused with recruitment fairs and presentations because it was not understood to be different. The least popular method of graduate recruitment in the UK was the use of recruitment agencies (20\%), which was the most popular method in France (46\%) and Spain (42\%). It should be noted that among the UK sample, the large employers used recruitment agencies more than the small ones especially for the recruitment of specialised and skilled employees. 'Other' included the use of the word of mouth and recommendations, which were popular in France (62\%) and Spain (83\%), headhunting, which was mentioned by $20 \%$ of the UK respondents and $5 \%$ of German respondents, unsolicited applications, which were mentioned by $76 \%$ of the French, $68 \%$ of the Spanish, $32 \%$ of the British and $12 \%$ of the German respondents and work placements or internships, which were high in Germany (98\%) and France (65\%) and low in Spain (22\%) and the UK (13\%).

\section{Selection methods}

Again, it was not surprising to find that the interview was the most common method of selection (Table 3) although the respondents did differ in their approach and level in the 
use of this method. All respondents used interviews in graduate recruitment but the method varied, with more than $50 \%$ of the German and UK respondents indicating that they had used more than one interview per applicant and about $40 \%$ indicating that they used both single interviewer and panel interviews; whereas in France and Spain, more than $50 \%$ of the respondents said they had used one interview. The use of panel interviewing was less common in Spain, with only $12 \%$ of the respondents using it. More than half $(53 \%)$ of the Spanish respondents said they had used a single interviewer but about $35 \%$ said they used a combination of interviewing techniques. Telephone interviews were also used by more than $70 \%$ of the British, $60 \%$ of the German, $43 \%$ of the French and $26 \%$ of the Spanish respondents who said that they had used it because it was convenient, cheap and saved time. The results also show that more than $70 \%$ of the respondents had application forms but only $37 \%$ had application forms designed specifically for the selection of graduate applicants. Also, more than $70 \%$ of the respondents used a CV together with a letter or an application form but only $26 \%$ relied on a CV alone. Short-listing in Spain and France was mainly based on the CV and the covering letter but in the UK and Germany the normal procedure started with the assessment of application forms depending on whether they were standard employer application forms, a job specific (graduate application) forms, or the combination of a $\mathrm{CV}$ and application form.

Table 3: Methods of graduate selection by country

\begin{tabular}{|l|ccccc|}
\hline \multicolumn{1}{|c}{ Country } & France & Germany & Spain & UK & Overall \\
\hline Method & $\%$ & $\%$ & $\%$ & $\%$ & $\%$ \\
\hline CV \& Letter & 95 & 72 & 83 & 68 & 80 \\
CV only & 24 & 26 & 25 & 30 & 26 \\
CV +Application & 75 & 82 & 64 & 91 & 78 \\
Employer application & 63 & 76 & 75 & 65 & 70 \\
Graduate application & 40 & 35 & 28 & 43 & 37 \\
Interviews & 100 & 100 & 100 & 100 & 100 \\
Tests & 72 & 75 & 60 & 62 & 67 \\
Assessment centres & 21 & 23 & 10 & 35 & 22 \\
References & 100 & 97 & 95 & 100 & 98 \\
Other & 27 & 20 & 12 & 10 & 17 \\
\hline
\end{tabular}


In the UK, $62 \%$ of employers, mainly large companies, used aptitude tests but they were more common in France (72\%) and Germany (75\%). More than a third (35\%) of the UK respondents used assessment centres but this is the highest with $21 \%$ using them in France, $23 \%$ in Germany and $10 \%$ in Spain. Although more than $98 \%$ of all respondents indicated that they had requested references, a third (34\%) did so only after offers had been made. This means that references were not used as a selection tool but to confirm information submitted by candidates. The most common qualities asked for in references were honesty, reliability, time keeping, punctuality, alongside information including confirmation of details, character, attendance, suitability, teamwork and performance. 'Other' included the successful completion of a work placement or internship, a good health report, completion of national service, having a work permit, having no criminal record and passing an entrance examination. These selection requirements differed from one country to another. For example, the German respondents mentioned work placements and good health report while Spanish respondents mentioned the health report, national service and entrance examination. The British respondents mentioned criminal record and work permit.

\section{Employer expectations}

Employer expectations (Table 4) varied depending on organisation size and the nature of their operations but it was interesting to note that the majority of the British and German respondents expected newly graduated students to have good transferable skills rather than excellent academic grades, whereas the majority of the French and the Spanish respondents emphasised excellent academic qualifications over transferable skills. Overall, nearly $70 \%$ of the respondents thought that degree classification was important and had considered only those applicants with at least a lower second-class honours degree or equivalent. This finding is consistent with the work of Ball (2014) who found that graduates with first-class degrees are less likely to be out of work than those with lower grades. The most required qualities were 'the willingness to learn' (81\%), 'teamwork' (73\%) and 'the desire to achieve and motivation' (72\%). Most of the respondents expected their potential employees to have good communication skills (oral and written), leadership skills, IT skills, dependability or reliability and confidence or assertiveness. German employers added professional competence and the ability to manage change. Spanish employers added language skills as an important factor while the French employers rated good knowledge of the job as another important attribute. 
Interestingly, drive and energy and research or inquiry skills were not rated highly by all respondents (48\% and 36\% respectively) but this may be a reflection of the type of organisations and sectors studied.

Moreover, the respondents were asked whether the place of higher education attended by the candidate would influence their chance of employment with the company. More than three-quarters (78\%) of the French and more than half (56\%) of the Spanish respondents said yes it would but only a third (33\%) of the British and about a quarter (26\%) of the German respondents thought the same way. However, of those who stated that it would, the British had no specific preferences because they either stated the 'top universities in the country' or 'universities offering relevant courses', whereas the French were more specific because most of them preferred graduates from the Grandes Écoles or Écoles Superieures. The Spanish respondents were less specific in their replies with equal numbers of respondents preferring colleges of higher education, old universities, technical schools, specialised business schools and universities with a high reputation. In general, the degree classification was more important than the type of college/university attended.

Table 4: Employers' expectations

\begin{tabular}{|l|c|c|c|c|c|}
\hline Attributes/skills & France & Germany & Spain & UK & Overall \\
\hline & $\%$ & $\%$ & $\%$ & $\%$ & $\%$ \\
Desire to achieve/motivation & 65 & 86 & 63 & 75 & 72 \\
Willingness to learn & 98 & 62 & 74 & 89 & 81 \\
Commitment/loyalty & 55 & 74 & 60 & 62 & 63 \\
Confidence/assertiveness & 62 & 68 & 55 & 73 & 65 \\
Dependability/reliability & 45 & 87 & 58 & 78 & 67 \\
Problem solving ability & 66 & 72 & 55 & 62 & 64 \\
Drive/energy & 42 & 45 & 48 & 57 & 48 \\
Teamwork & 72 & 68 & 75 & 77 & 73 \\
Oral communication skills & 83 & 56 & 52 & 65 & 64 \\
Written communication skills & 85 & 55 & 40 & 68 & 62 \\
IT skills & 65 & 73 & 65 & 67 & 68 \\
Presentation skills & 66 & 47 & 58 & 68 & 60 \\
Time management & 43 & 82 & 46 & 56 & 58 \\
\hline
\end{tabular}




\begin{tabular}{|l|l|l|l|l|l|}
\hline Degree classification & 75 & 60 & 78 & 62 & 69 \\
Type of college/university & 78 & 26 & 56 & 33 & 48 \\
Subject/discipline & 63 & 58 & 64 & 54 & 60 \\
Entrepreneurial skills & 46 & 50 & 56 & 60 & 53 \\
Leadership skills & 60 & 65 & 45 & 68 & 60 \\
Research/inquiry skills & 38 & 40 & 30 & 35 & 36 \\
Other (business awareness, & 25 & 30 & 28 & 23 & 27 \\
ethical thinking, potential, & & & & & \\
decisiveness) & & & & & \\
\hline
\end{tabular}

\section{Graduate expectations and experiences}

The analysis of data collected about the expectations and experiences of final-year students revealed more similarities than differences among the graduates of the four countries studied. In general, career progression, training opportunities, good salary and benefits were among the factors most expected by graduates. More than $90 \%$ of students from the UK sample considered training opportunities and the reputation of the company as highly important. More British and Spanish than French or German respondents thought that pay and benefits were important features in their choice of future employer. However, the majority of the respondents did not consider the work location to be important. This shows that new graduates are willing to work in anywhere in the EU for the right job. Also, most of the respondents did not consider caring for the environment to be important in their choice of potential employer. Job security was seen to be very important while flexible working hours were not. This is possibly because most of the graduates studied did not have family commitments and therefore work-family balance was not yet an issue for them. This finding is inconsistent with the study PwC (2011) that found young people gave more weight to flexible working than to monetary rewards. One possible explanation is that the respondents of $\mathrm{PwC}$ (2011) come from wealthier backgrounds or that family commitments are more important to them. 'Other' included travelling, sports facilities, ethical behaviour, equality and fairness, which were mentioned by $26 \%$ of the respondents.

Table 5: Graduates' expectations

\begin{tabular}{|l|c|c|c|c|c|}
\hline Expectations & France & Germany & Spain & UK & Overall \\
\hline
\end{tabular}




\begin{tabular}{|l|l|l|l|l|l|}
\hline & $\%$ & $\%$ & $\%$ & $\%$ & $\%$ \\
Career progression & 86 & 90 & 78 & 88 & 86 \\
Training opportunities & 75 & 73 & 78 & 92 & 80 \\
Salary & 80 & 82 & 95 & 83 & 85 \\
Benefits and allowances & 77 & 67 & 80 & 78 & 76 \\
Reputation & 60 & 80 & 45 & 90 & 69 \\
Caring for the environment & 20 & 34 & 10 & 38 & 26 \\
Location & 25 & 16 & 05 & 20 & 17 \\
Good working environment & 55 & 50 & 43 & 45 & 50 \\
Flexible working hours & 42 & 33 & 28 & 43 & 33 \\
Job security & 75 & 66 & 78 & 70 & 72 \\
Other (travelling, fairness, & 24 & 37 & 12 & 32 & 26 \\
equality, sports facilities, ethical & & & & & \\
behaviour) & & & & & \\
\hline
\end{tabular}

The majority of the respondents found the use of the Internet a convenient way of finding graduate jobs but this varied slightly from one country to another. More German and French than British and Spanish students used the Internet regularly to look for jobs. Newspaper advertisements are still widely used but were the most common method used by students in Spain and the least by students in Germany. Other ways by which students became aware of vacancies in all four countries included word of mouth, networking, recruitment agencies and previous employees but word of mouth and the use of friends and relatives were more common in France and Spain than in Germany or the UK. This confirms the responses, above, made by employers in relation to the methods of recruitment they used. .

Most of the respondents found the use of the CV and covering letter cost effective, the use of application forms time consuming and the use of interviews a daunting experience. However, most of the respondents among the graduating students indicated that interviews were important for both the candidate and the employer. Over $50 \%$ of the respondents stated that their lack of experience of being interviewed made them unable to answer certain interview questions and that the impressions they got at the interview affected their decision to accept or reject the offer of a job. Most of the French and Spanish respondents found interviews too formal and intimidating. By contrast, most of the British and German 
respondents found interviews informal and friendly and a learning experience. Most of the students found aptitude tests to be stressful and not an accurate reflection of ability and that they had little relevance to real life activities because of their subjective nature. Assessment centres were found to give a good overall evaluation of applicant performance because they use a variety of selection methods but they were found to be highly demanding and stressful especially for those who found socialising and working in a group difficult. Work placements were found to be very useful and rewarding to both the candidate and the employer, especially by the German and the French respondents. However, some students from the UK and Spain felt that work placements had not been used for developmental purposes especially when the student was treated as an extra employee to do trivial and repetitive tasks.

\section{Discussion}

The analysis of the findings leads to the conclusion that there are more similarities than differences in the process of graduate recruitment and selection among the four countries studied. This partly supports some of the previous studies on the subject of graduate employment in the EU countries (Little, 2008; Branine, 2008, Brennan and Little, 2010) but the objective of this paper is to also investigate the employability of graduates in EU labour markets and the possibility of developing a common approach or model of graduate recruitment. To meet this objective, it has been important to explore the correlation between organisational features (graduate expectations) and graduate attributes (employer expectations) and the role of institutions of higher education as the intermediary factor.

This study confirms the existence of common expectations of employers among EU graduates. This supports Brennan and Little's (2010, p. 9) conclusion that 'the UK graduates did not differ significantly from other European graduates in their perception of the competencies required of them and the extent to which they were possessed'. It seems that the graduates' choice of their potential employers and the employers' expectations of graduates' attributes or qualities are influenced by economic and organisational rather than social and political factors. The equation is very simple. Most graduates look for jobs that would provide them with career progression, training opportunities, a good salary and benefits and employment security while most employers look for graduates who are motivated and willing to learn and to work in teams and have good communication skills 
(oral and written), leadership skills and IT skills. This simple equation requires the efficient involvement of a common denominator that is institutions of higher education. Some of the differences in graduate recruitment between the countries studied are mainly to do with the current differences in higher education systems.

The link between higher education institutions and the employers) is the labour market. Higher education institutions are expected to control the supply side and employers are responsible for the demand side of the market. Understanding the supply and demand sides of the graduate labour market is of paramount importance for the development of appropriate approaches to graduate recruitment and selection. Higher education institutions play a significant role in preparing graduates for future employment. Therefore, a stronger fit between higher education and the labour market could make the transition from formal education to the world of work easier and the process of graduate recruitment clearer to both employers and graduates.

\section{Conclusions}

The most popular method of graduate recruitment was the Internet, followed by graduate recruitment literature such as brochures, newsletters and national graduate recruitment directories and finally newspapers/magazines. This has implications for recruitment practice becoming more global as the Internet has no boundaries, whereas higher education institutions have more input into the more localised graduate recruitment services. With respect to the selection process it is not surprising that the interview is the most common method of selection, however, it is important to notice that references are an important contributor to the selection decisions. This supports the acknowledged view that the reliability and validity of interviews is quite low (Huffcutt et al., 2013; Marchese and Muchinsky, 1993; Posthuma et al., 2002), hence there is a need to cross-match the interview outcome with references to create a more reliable measure of future performance, these findings are consistent with across all four EU countries.

Employer expectations however vary from country to country. The highest scores attributed by French, Spanish and British employers relate to such attributes as 'willingness to learn', with German employers more concerned about efficiency of graduates in the context of reliability and time management. The ability to work in a team 
and being motivated are to some extent named by all employers as important, corroborating the numerous employability related studies (Brown et al., 2003; Hillage and Pollard, 1998; McQuaid and Lindsay, 2005; Pegg et al., 2012; Rae, 2007; Yorke and Knight, 2006). Despite common belief (Wilton, 2008), such skills as research or inquiry are not rated highly by all surveyed employers, however this finding can be rationalised with the reference to the types of organisations and sectors studied.

The findings stemming from the analysis of the expectations of graduates indicate certain similarities across all four EU countries. The graduates have high expectations of career progression, training opportunities, good salary and benefits amongst all other factors. This finding contradicts the PwC (2011) study indicating that young people put more weight on flexible working than monetary rewards. This may be attributed to the age factor of the respondents in both studies as well as their financial background, neither parameter has been controlled within this study.

Further study of graduate recruitment in the EU labour market needs to look at graduate employment within different sectors and types of companies (for example, large versus small), while considering some key demographic variables such as the age of graduates and their financial background.

The process of graduate recruitment and the prospects of graduate employment in the EU are still under-researched and open to contradictory interpretations. This study attempted to explore the employability prospects of graduates in four EU labour markets where more and more students from one country are graduating from universities of other countries and are likely to be employed in their home country or in third countries. The study examines the process of graduate recruitment, employee and employer expectations and the role of higher education institutions in meeting such expectations. The findings suggest that although differences between the recruitment and selection procedures do exist, these are not at opposite ends of the scale. All countries studied are found to use similar methods but to varying degrees. It would be possible to combine procedures to develop a common system with some nationally based variations.

Higher education systems within the EU are still different but they are undergoing substantial changes, among which the commitment to meeting the Bologna declaration 
objectives is the most significant one. With the implementation of the Bologna declaration it will even become possible to have a common degree structure and to develop a panEuropean model of graduate recruitment and selection. This study will be of use to graduates of all nationalities who wish to seek employment in the EU and to graduate employers who wish to have a wider pool of graduate applicants with a variety of skills and abilities.

\section{References}

Anderson, N. and Shackleton, V. (1990) 'Decision-making in the graduate selection interview', Journal of Occupational Psychology, Vol.63, No.1, pp.63-76

Anderson, N. and Witvliet, C. (2008), 'Fairness Reactions to Personnel Selection Methods: an international comparison between the Netherlands, the United States, France, Spain, Portugal, and Singapore', International Journal of Selection and Assessment, Vol. 16, No. 1, pp.1-13

Archer, W.H. and Raban, A. J. (1995), Working in the European Union, $4^{\text {th }}$ Edition, London: Hobson Publishing.

Ball, C. (2014), 'Getting a first versus work experience: your employability prospects in full', The Guardian, 7 April 2014, available from: http://careers.theguardian.com/firstdegree-employability-work-experience [Accessed on 18 June 2014]

Boden, R. and Nedeva, M. (2010), 'Employing discourse: universities and graduate employability', Journal of Education Policy, Vol. 25, No. 1, pp.37-54

Branine, M. (2008), 'Graduate recruitment and selection in the UK: a study of the recent changes in methods and expectations', Career Development International, 13(6):.497-513

Brennan, J. and Little, B. (2010), 'Graduate competences and relationships with the labour market: The UK case', paper presented at the international conference on Development of Competences in the World of Work and Education, 24-26 September, 2009, Ljubjana, Slovenia

Brewster, C. (1998), 'Flexible working in Europe: extent, growth and challenge for HRM', in P. Sparrow and M. Marchington (eds.), HRM: The new agenda, Pittman: London, Chapter 16, pp.245-258

Broadbridge, A.M., Maxwell, G.A. and Ogden, S.M. (2009), 'Selling retailing to Generation Y graduates: recruitment challenges and opportunities', The International Review of Retail, Distribution and Consumer Research, Vol.19, No.4, pp.405-420

Brown, P. And Hesketh, A. (2004), The mismanagement of talent, Oxford: Oxford University Press. 
Brown, P.; Hesketh, A. and Williams, S. (2003),'Employability in a knowledge-driven economy', Journal of education and work, Vol. 16, No. 2, pp. 107-126.

Browne, L. (2010), 'As UK policy strives to make access to higher education easier for all, is discrimination in employment practice still apparent?', Journal of Vocational Education and Training, Vol.62, No.3, pp.313-326

Burgess, P. (1990) (ed.), European Management Guides: Recruitment, London: Institute of Personnel Management.

Cable, D. M. and Judge, T. A. (1994), 'Pay preferences and job search decisions: A person-organisation fit perspective', Personnel Psychology, Vol. 47, No. 2, pp. 317-348.

Camagni, R.; Capello, R. and Capello, R. (2012), "Globalization and economic crisis: How will the future of European regions look", in Capello, R. and Dentinho, T. P. (Ed.), Globalization Trends and Regional Development: Dynamics of FDI and Human Capital Flows, UK: Edward Elgar Publishing.

Carroll, M. Marchington, M.; Earnshaw, J. and Taylor, S. (1999), "Recruitment in small firms: Processes, methods and problems", Employee Relations, Vol. 21, No. 3, pp.236 250 .

CEP (Centre for Economic Performance) (2004), Annual Report: 2002-2003, CEPLondon school of Economics and Political Science: London

Chillas, S. (2010), 'Degrees of Fit? Matching in the graduate labour market', Employee Relations, Vol.32, No.2, pp.156-170.

CIPD (Charted Institute of Personnel and Development) (2007), Annual Survey Report 2007: Recruitment, Retention and Turnover, London: CIPD [online] Available from: http://www.cipd.co.uk/NR/rdonlyres/746F1183-3941-4E6A-9EF6-

135C29AE22C9/0/recruitmentsurv07.pdf [Accessed on 26 March 2014]

CIPD (Charted Institute of Personnel and Development) (2013), Resourcing and talent planning 2013, London: CIPD [online] Available from: http://www.cipd.co.uk/binaries/6226\%20RTP\%20SR\%20WEB.PDF [Accessed 26 March 2014].

Dany, F. and Torchy, V. (1994), 'Recruitment and selection in Europe: Policies, practices and methods', in Brewster, C. and Hegewisch, A. (eds.), Policy and Practice in European Human Resource Management: The Price Waterhouse Cranfield Survey, Routledge: London, Chapter 5, pp.68-88

Department for Business Innovation and Skills (2009), Higher ambitions, the future of universities in a knowledge economy, London: HMSO.

Department for Education and Skills (DfES) (2007), Bologna Process-Excellence through engagement, Nottingham: DfES [online], available from: http://www.seeeducoop.net/education_in/pdf/11\%20Excellence_FINALv2.pdf, [Accessed on 26 March 2014]. 
Dima, Alina Mihaela (2014) (ed.), Handbook of Research on Trends in European Higher Education, IGI Global

Economist (2011), 'Got Talent?', $10^{\text {th }}$ Sept 2011, Available from: http://www.economist.com/node/21528436 [Accessed 18 June 2014]

Etzkowitz, H. and Leydesdorff, L. (eds.) (1997), University and the Global Knowledge Economy, London: Pinter

Elias, P. and Purcell, K. (2004), "Is Mass Higher Education Working? Evidence from the Labour Market Experiences of Recent Graduates", National Institute Economic Review, Vol. 190, No. 1, pp. 60-74.

Eurostat (2007), Labour force survey in the EU, Candidate and EFTA Countries: main characteristics of the national surveys 2005, Brussels: European Commission.

Eurostat (2014), Unemployment statistics, Brussels: European Commission [Online], available from:

http://epp.eurostat.ec.europa.eu/statistics_explained/index.php/Unemployment_statistics [Accessed on 17 June 2014].

Felstead, A., Gallie, D., Green, F. And Zhou, Y. (2007), Skills at Work 1986-2006, ESRC: Oxford, UK.

Garavan, T. N. (2007), 'Using assessment centre performance to predict subjective person-organisation (P-O) fit: A longitudinal study of graduates', Journal of Managerial Psychology, Vol. 22, No. 2, pp.150- 167

Gush, J. (1996a), 'Assessing the role of higher education in meeting the needs of the retail sector', Education +Training, Vol.38, No.9, pp.5-13

Harvey, L. (2001), 'Defining and measuring employability', Quality in Higher Education, Vol. 7, No. 2, pp. 97-110.

Helyer, R. and Lee, D. (2012), 'The twenty-first century multiple generation workforce: Overlaps and differences but also challenges and benefits', Education + Training, Vol.54, No.7, pp.566-578

Higher Education Statistics Agency (HESA) (2014), Qualifications obtained by level, sex and subject, Cheltenham: HESA [Online], available from: http://www.hesa.ac.uk/dox/pressOffice/sfr197/280607_student_sfr197_1213_table_10.xls $\underline{\mathrm{x}}$ [Accessed on 28 April 2014].

High Fliers (2014), The Graduate Market in 2014, London: High Fliers Research Limited [Online], available from: http://www.highfliers.co.uk/download/GMReport14.pdf [Accessed 28 April 2014].

Hillage, J. and Pollard, E. (1998), 'Employability: developing a frame work for policy analysis', Research Brief No. 85, London: Department for Education and Employment 
[Online],

available

https://www.education.gov.uk/publications/eOrderingDownload/RB85.pdf [Accessed 17 June 2014].

Hilton, M. (2008), 'Skills for Work in the 21st Century: What Does the Research Tell Us?', Academy of Management Perspective, 22(4), pp. 63-78.

Hodgkinson, G.P., Daley, N. and Payne, R.L. (1995), 'Knowledge of, and attitudes towards, the demographic time bomb: A survey of its impact on graduate recruitment in the UK', International Journal of Manpower, 16(8), pp. 59-76.

Huffcutt, A. I., Culbertson, S. S. and Weyhrauch, W. S. (2013), 'Employment Interview Reliability: New meta-analytic estimates by structure and format', International Journal of Selection and Assessment, Vol. 21, No. 3, pp. 264-276.

Hurrell, S.A., Warhurst, C. and Nickson, D. (2011), 'Giving Miss Marple a Makeover: Graduate Recruitment, Systems Failure, and the Scottish Voluntary Sector', Nonprofit and Voluntary Sector Quarterly, 40(2), pp. 336-355

Iannelli, C. (2007), 'Inequalities in Entry to Higher Education: a Comparison Over Time between Scotland and England and Wales', Higher Education Quarterly, 61(3), pp 306333.

Jung, H. (2006), Personalwirtschaft, $7^{\text {th }}$ ed. München: R. Oldenbourg Verlag.

Keenan, T. (1995), 'Graduate recruitment in Britain: a survey of selection methods used by organization', Journal of Organizational Behaviour, 16(3), pp. 303-317

Krings, T. (2006), 'Meeting Metro: A Case Study', European Retail Digest, 22 June. Available from: http://www.highbeam.com/doc/1G1-154334354.html [Accessed 26 March 2014].

Lauterbach, U. (2008), »Evaluating progress of European vocational education and training systems: indicators in education«, Journal of European Industrial Training, $32(2 / 3)$, pp. $201-220$

Lievens, F., Decaesteker, C., Coetsier, P. and Geirnaert, J. (2001), 'Organizational Attractiveness for Prospective Applicants: A Person-Organisation Fit Perspective', Applied Psychology: An International Review, 50(1), pp. 30-51.

Little, B. (2008), 'Graduate development in European employment: issues and contradictions', Education + Training, 50(5), pp. 379-390

Marchese, M. C. and Muchinsky, P. M. (1993), 'The Validity of the Employment Interview: A Meta-Analysis', International Journal of Selection and Assessment, 1(1), pp. $18-26$.

McKeown, T. and Lindorf, M. (2010), 'The graduate job search process-a lesson in persistence rather than good career management?', Education +Training, 53(1), pp. 310320 
McQuaid, R. W. and Lindsay, C. (2005), 'The concept of employability', Urban studies, Vol. 42, No. 2, 197-219.

Mazuki, J., Maimun, S. and Siong, C.C. (2011), 'Expectations gaps, job satisfaction, and organizational commitment of fresh graduates: Roles of graduates, higher learning institutions and employers', Education + Training, 53(6), pp. 515-530

Maringe, F. and Foskett, N. (2012), Globalization and Internationalization in Higher Education: Theoretical, Strategic and Management Perspectives, UK: continuum International Publishing Group.

Montgomery, D.B. and Ramus, C.A. (2011), 'Calibrating MBA Job Preferences for the $21^{\text {st }}$ Century', Academy of Management Learning \& Education, 10(1), pp. 9-26

Mourshed, M.; Patel, J. and Suder, K. (2014), Education to Employment:

Getting Europe's Youth into Work, McKinsey and Company, [Online], available from: http://www.mckinsey.com/Insights/Social_Sector/Converting_education_to_employment in_Europe [Accessed 28 April 2014].

Nabi, G.R. and Bagley, D. (1999), 'Graduates Perceptions of Transferable Personal Skills and Future Career Preparation in the United Kingdom', Education and Training, 41(4), pp.184-193

Office for National Statistics (ONS) (2013), Graduates in the UK Labour Market 2013, London: ONS [Online], available from:

http://www.ons.gov.uk/ons/dcp171776_337841.pdf [Accessed 28 April 2014].

Office for National Statistics (ONS) (2014), Young people in labour market, London: ONS [Online], available from: http://www.ons.gov.uk/ons/rel/lmac/young-people-in-thelabour-market/2014/rpt-young-people.html\#tab-Participation-in-full-time-education [Accessed 18 June 2014].

Pegg, A.; Waldock, J.; Hendy-Isaac, S. and Lawton, R. (2012), Pedagogy for Employability, York: Higher Education Academy [Online], available from: http://www.heacademy.ac.uk/assets/documents/employability/pedagogy_for_employabilit y_update_2012.pdf [Accessed 17 June 2014].

Posthuma, R. A., Morgeson, F. P. and Campion, M. A. (2002), 'Beyond employment interview validity: a comprehensive narrative review of recent research and trends over time', Personnel Psychology, 55(1), pp. 1-81.

Purcell, K., Elias, P. and Davies, R. (2005), The Class of '99: A Study of the Early Labour Market Experience of Recent Graduates, Research Report 691, Sheffield: Department for Education and Skills

Purcell, K., Elias, P. and Wilton, N. (2006), Looking through the Glass Ceiling: a Detailed Investigation of the Factors that Contribute to gendered Career Inequalities, Report to the European social Fund: Liverpool: European Social Fund 
PwC (2011), Millennials at work: Reshaping the workplace, PricewaterhouseCoopers International Limited. [Online] available from: http://www.pwc.com/en_M1/m1/services/consulting/documents/millennials-at-work.pdf [Accessed 25 March 2014].

Rae, D. (2007), 'Connecting enterprise and graduate employability: Challenges to the higher education culture and curriculum?', Education + Training, 49(8/9), pp. 605-619.

Rauner, F. (2008), 'European vocational education and training: a prerequisite for mobility?', Journal of European Industrial Training, Vol.32, No.2/3, pp.85-98

Reid, M. A. and Barrington, H. (1997), Training Interventions: Managing Employee Development, $5^{\text {th }}$ edition, London: Institute of Personnel and Development

Sackett, P.R. and Lievens, F. (2008), 'Personnel Selection', Annual Review of Psychology, 59 (1), pp. 419-450.

Stephan, M. and Silvia, M. (2008), 'A dynamic perspective on next-generation offshoring: The global sourcing of science and engineering talent', Academy of Management Perspectives, 22(3), pp. 35-54.

Stewart, J. and Knowles, V. (1999), 'The changing nature of graduate careers', Career Development International, 4(7) , pp.370-383

Straub, C. (2007), 'A comparative analysis of the use of work-life balance practices in Europe: Do practices enhance females' career advancement', Women in Management Review, Vol.22, No.4, pp. 289-304

Swain, P. (1999), 'Organisational Learning: Developing leaders in a strategic human resource perspective', The Learning Organization, 6(1), pp. 30-39

Terjesen, S., Vinnicombe, S. and Freeman, C. (2007), 'Attracting generation Y graduates: Organisational attributes, likelihood to apply and sex differences', Career Development International, 12(6), pp. 504-522

Tixier, M. (1996), 'Employers' recruitment tools across Europe', Employee Relations, Vol. 18, No.6, pp.69-80

Van Hoye, G. and Lievens, F. (2007), "Social Influences on Organizational Attractiveness: Investigating If and When Word of Mouth Matters", Journal of Applied Social Psychology, Vol. 37, No. 9, pp. 2024-2047.

Wachter, B. (2004), "The Bologna Process: developments and prospects", European Journal of Education, Vol. 39, No. 3, pp. 265-273.

Weitzel, T. et al. (2008), Recruiting Trends 2008, Eine empirische Untersuchung mit den Top 1000 Untermehmen in Deutschland sowie den top 300-Unternehmen aus den Branchen Energieversorgung, Gesundheit und wellness sowie Informationstechnologie. Frankfurt: Centre of Human Resources Information Systems. 
Wilton, N. (2008), 'Business graduates and management jobs: An employability match made in heaven?', Journal of education and work, 21(2), pp. 143-158.

Wilton, N. (2011), 'Do employability skills really matter in the UK graduate labour market? The case of business and management graduates', Work, employment and society, 25(1), pp. 85-100.

Yorke, M., Knight, P.T. (2006), Embedding Employability into the Curriculum, York: Higher Education Academy. 